\title{
Stigmergic behaviour and nodal places in residential areas: Case of post-socialist city Kharkiv in Ukraine
}

\author{
Oksana Chabanyuk ${ }^{1}$, Miguel Ângelo Fonseca ${ }^{2}$ \\ ${ }^{1}$ Department of Architectural Environment Design, Faculty of Architecture, Kharkiv National \\ University of Civil Engineering and Architecture, e-mail: oxichabanyuk@gmail.com, ORCID: 0000- \\ 0002-1724-7275 \\ ${ }^{2}$ CIAUD FA ULisboa, Architecture Faculty, University of Lisbon, e-mail: miguelfonseca.ciaud@ \\ fa.ulisboa.pt, ORCID: 0000-0003-3117-8920
}

\begin{abstract}
The study of urban development and regeneration of residential areas in the cities are mainly focused on the separate infrastructural systems and less how networks of infrastructural systems and their elements, as nodal places, interact with the existing living environment and its urban tissue. The central goal of the paper is to examine contemporary residential areas of low liveability with nodal places of logistics and services infrastructural networks, with an eye on existing urban policies and application of transdisciplinary concept of stigmergy in contemporary urban environment. Research objectives: (a) conceptualisation of stigmergic process in urban planning; (b) overview of socialist and post-socialist urban policies for residential areas; (c) stigmergic behaviour in the development of nodal places in residential areas. Methodology: Use of Earth Time Observation Systems for identification of urban changes of nodal places under the stigmergic behaviour in the case study residential area in post-socialist city in Ukraine; contextualization of the case study with the categories: Ideology, Institutional level, Politics, Economics, Mobile Infrastructures. Discussion and conclusion: (a) as concept, stigmergic behaviours are efficient, but work as a self-organization form; (b) urban policies should, under the stigmergic behaviours, contextualize changes, continue or prevent the process.
\end{abstract}

Keywords: nodal places; urban policies; post-socialist city; residential areas; stigmergy; stigmergic behaviour

\section{Introduction}

The research of urban development and regeneration of residential areas in the cities are mainly focused on the separate infrastructure systems [1,2] and less how networks of infrastructure systems and their elements, as nodal places, interact with the existing living environment and its urban tissue. A nodal place, a node, is a morphological element of a network, a "concentrations of activities" [3], "concentrations of land uses in a geographical area" [4], an integral component [5] or sub-centre, the focus of specific concentrations [4], a vertex in the theory of networks [6]. The nodes are connected in the network by means of "diverse links", "space of flows" [5]. The nature of networks received diverse meanings in various fields, natural and artificial (built) sense, material and non-tangible areas. The diversity of the networks challenges the developing of ways, in which these formal and informal networks are coupled, layered to one another, the way processes spread and diffuse 
over the links $[6,7]$. The social networks, their behaviours, memory of the place, and other informal networks are present in the society and its environment of space, living and urban place; hence envisage the use of applied transdisciplinary concepts of networks development.

Urban planning mutually comprises the built networks, infrastructures, which serve to create liveable urban environment for citizens. Networks of infrastructure systems are a "subsystem of urban structure, which supports production and development of the city" [5], and its living environment in the residential areas. The meaning of development and regeneration of residential areas in the cities involves the development of elements of infrastructures as nodal places, which cumulate and integrate the activities to the urban environment. This process demands research-based steps to understand the changes in the society, which lead to the development of the activities, need of functions and facilities in urban environment. Hence, the support with urban policies for effective urban development becomes an integral question for the contemporary city, which will cumulate knowledge of networks integration, economic changes, societal influences and needs, and in particular networks' structural elements.

The experience of development and implementation of urban policies for territories in the cities received challenges in the approaches in various countries. The environment in the European cities, in particular the residential areas, during the stages of the development, faced challenges in the processes of urban policies during the last decades. For instance, the Netherlands that had been much concerned on social housing questions among other Western European countries, as well as on urban renewal and regeneration faced that in the 1980s "the policies of different ministries as regards objectives, available resources and even the designation of problem areas, moved further and further away from one another, creating a real patchwork of urban policies and problems" [8]. A decade ago "the Dutch national urbanisation policy [...] is often said to be inadequate and not a timely answer to societal changes" [4]. Cheng et al. [4] states that, "any policy-making must be based on the proper understanding of the network", development of infrastructural system in the cities.

The contemporary city faces the changes in the societies, thus should aim the development in the framework of up-to-date visions and strategies. It is New Urban Agenda by United Nations Conference on Housing and Sustainable Urban Development (Habitat III) [9] that stresses the attention on "readdressing the way cities and human settlements are planned, designed, financed, developed". This deep declaration actualizes the questing of understanding of the urban processes, its networks and societal influences. Michael Batty in his The New Science of Cities [7] expresses the statement, there is now considerable momentum in developing formal ideas about how cities are ordered and structured. A new paradigm is emerging". This opens the possibility to involve contemporary transdisciplinary approaches to understanding of needs, influences and challenges in the cities today. There are attempts in transdisciplinary urban researches with other disciplines (computation, biology, other) to apply and built the stigmergic approaches in understanding of: cities' system elements as urban street networks [10]; generating of street networks in urban context based on minimum spanning trees computation [11]; urban activity patterns from positioning data in crowds urban dynamics [12]; urban processes of self-organization and emergence [13]. Nevertheless, the concept of stigmergy is not widely used in urban planning theory by now, new transdisciplinary applications continue emerging with increasing number of application domains. Heylighen underlines that "as yet under investigated application of stigmergy to human affairs opens the way to a virtually limitless expansion across the various scientific, technological and social disciplines that study society, cognition, and behaviour" $[14,15]$. 
Hence, stigmergy opens broader possibilities for analysis of the development of the city, its networks and processes.

In this paper, we are addressing to the transdisciplinary concept of stigmergy to examine contemporary urban environment of residential areas and its nodal places at the time of changing economies, policies and societal influences. This paper thus focuses on understanding of application of transdisciplinary concept of stigmergy and conceptualisation of stigmergic process in urban planning. It is considered to examine the stigmergic approach in the developing environments, such as post-socialist cities, as they face much deep challenges in their liveability then urban environments in developed societies. The special interest is put on residential areas of low liveability with nodal places of logistics and services infrastructural networks, with an eye on changes, challenges and urban policies. We refer the living environment of low liveability in residential areas in the cities as the residential areas of prefabricated housing estates with living environment of low quality in the postsocialist city. This typology of residential environment draws our attention because is based on the socialist ideology in the state planning system approach as 'administrative planning design' in a socialist city during the time of existing of the USSR. Today these residential areas receive non-systematic changes in functioning around and in their nodal places. The study is guided by the conjecture that define the research hypothesis: the application of the transdisciplinary concept of stigmergy and stigmergic behaviours in urban planning envisage contextualization of changes by urban policies.

The article is structured as follows. The „Stigmergic concept and behaviors, related work and general approach" subsection of Introduction describes concept of stigmergy as a selforganization form and stigmergic behaviour both in general and transdisciplinary approach. The "Contextualization of the research" subsection of Introduction goes to the overview and justification of the context of the research to post-socialist living environment looking on: (a) socialist and post-socialist residential areas transformations under the stigmergic behaviour; (b) informal non-systemic urban development leads to functional changes. The section "Research objectives and methodology" defines and explains the content of the objectives, hypothesis and methodology of the study, which form the research design structure. The following section "Case study analysis: stigmergic behaviour and nodal places in residential area Saltivka District (Kharkiv)" aims to analyze the justified case study in post-socialist city addressing functional transformations in residential area as a stigmergic behaviour during the 1980s to 2017 under the cross-related stigmergic contexts (ideology, politics, economics, other) and categories (Actors, Time, Place, Actions). The "Discussion and conclusions" section summarizes the key findings about urban policies and stigmergic behaviour in urban planning, opens the floor for further research.

\subsection{Stigmergic concept and behaviors, related work and general approach}

The concept of stigmergy comes from entomology, a biology specialty devoted to the study of insects in all its aspects, as well as their relationships with man, plants and animals, and the environment [16]. The concept was first developed by Pierre-Paul Grassé in his study of the termite of 1959, applying it to his behavior. These behaviors differed according to the point of observation, being that: (a) as a group, the termites cooperate for the construction of their nests; and (b) as individuals, termites seem to work without any involvement in any collective work. Termites, as well as different sets of social insects, interact stigmergically, that is, their communication is characterized by reactions to changes in the environment and 
not by direct transmission of signals [17].

The concept of stigmergy, although it has already crystallized definitions of its meaning, is still to be explored in different disciplinary areas [18]. It is assumed that stigmergy is a model where a collective of agents exhibits the ability to face complex problems in selforganization, as are the examples found in social insects, contributing to the development of the disciplinary areas of Collective Intelligence, Swarm Intelligence or Emergent Behavior [19]. This capacity for self-organization, without benefits of central control or direct communication between different actors, is determined by the agents' reaction to continuous environmental changes [17].

As a computational programming language, the concept of stigmergy is used in synthesis, considering that the action of an agent in an environment stimulates a reaction, established by predetermined rules, in other agents that, in turn, the leads to intervene and modify this same environment. For example, ants detecting a certain degree of pheromone concentration, left by other ants in a path, are encouraged to intensify it. Conversely, the evaporation of the same pheromone in a course, promoted by the absence of ants, leads to its abandonment by other ants. Through the replication of this model it is possible to identify and analyze patterns of urban activities, observing their spatial and temporal dynamics [12].

In the Artistic area, the stigmergy concept finds relevance in approaches motivated by Artificial Intelligence, where the examples of Swarm Painting up to Artsbot, from the Robot Art collection of the Portuguese artist Leonel Moura, reveal the application of algorithms of artificial intelligence for the development of Artificial Creativity, in models of selforganization without control or hierarchy [20]. As Leonel Moura affirms, it is understood that the concept of stigmergy can be applied to mechanisms of cooperation between animals, as well as to urban, social, cultural or political phenomena [21]. Indeed, the very idea of Leonel Moura's city, in a wider context and analyzed in the light of the concept of stigmergy, indicates that these are no more than „,...) true social pheromone peaks (stimuli), capable of attracting everything and everyone around them" [21].

However, in a deeper approach, the same author differentiates levels of stimulus that characterize the processes of self-organization and stigmergy in the construction of the city, resulting from a permanent confrontation of interests and expectations, identifying: a) the construction and destruction as , ,...) the product of individual action and conjunctural collective agreements.”; and b) the planning and resulting political decision „(...) of the activity of multiple agents (...)" [21].

\subsection{Contextualization of the research}

Justification of the context of the research to post-socialist living environment. This subsection justifies the context for examination of stigmergy in urban environment. We suggest addressing stigmergic approach in the developing environment of post-socialist cities, which receive challenges in liveability of urban environment, and residential areas in particular, which are much more significant than in the developed societies. At the same time, the residential areas in the post-socialist cities face non-systematic transformations and changes, informal interventions after the collapse of the USSR in 1991. This applied research is contextualized within the environment of residential areas of low quality in the post-socialist city in the post USSR territory with the case of Ukraine.

Regarding the features and quality of the residential areas in post-socialist city, where the non-systematic transformations and informal interventions with trade function were and 
are situated, it is important to clarify the ideological principles of socialism, integrated to the development of the residential areas. The planning typology of residential areas in postsocialist city was strictly organized according to the socialist ideology implemented in the 'administrative planning design' during the USSR. The planning design of residential areas during the Soviet era embraced the next principles of socialist ideology: (a) administrative totally centralized urban planning and design mechanism, which had been performed only through state design institutes; (b) the residential areas were designed according the 'free planning' system and micro district division of its territory and public facilities; (c) the most economic prefabricated housing typical (series) projects of prefabricated housing, which were constructed in the cities on the whole territory of the Soviet Union; (d) common facilities (kitchens, canteens, bath etc.) in the 'communes' during the early Soviet period; (e) housing policies declared the minimum of living space for each family member in the small apartment; (f) no private housing for the citizens - the state was the only owner, which led to citizens' dependence from their place of work. These socialist principles crucially influenced on the quality of the living estates of prefabricated housing from 1954, time of beginning of prefabricated housing constructions in the USSR, till 1991, which was the time of its collapse. The quality of this living environment was low enough from the moment of construction of the housing.

The predominant typology for housing in the socialist cities during 1954-1980s was prefabricated multi-family housing block. The quantity of constructed dwelling according to the typical projects in the USSR had been rising from year to year, for instance, in 1958-77\%; $1960-88 \%, 1965-95 \%$ [22]. Hence, three quarters of citizen lived in the prefabricated housing by 1991, and today we receive the similar statistics: $63,8 \%$ of typical housing among all housing in the city in Kiev, 81,8\% - in Donetsk [23]; 85,2\% - in Kharkiv [24].

The scale of residential areas in the socialist city was planned according to the state norms and differed during the time. The planning unit for the urban development of residential area was a micro district. The planned quantity of population for such a micro district was defined in the state norms taking into consideration the size of the city (small, medium, huge, etc.). For instance, according to the state norms [25], the micro district in a city with total population from 500 to 1000 thousands citizens had to be planned for 12000-20000 inhabitants, with the density of $170-220$ persons/ha. The open free spaces between the housing blocks served to fulfil the norms of natural insolation of dwellings, but functionally were not fully occupied and caused appearance of big empty spaces.

Informal urban developments - functional changes. The functioning of the contemporary living environment, therefore networks and nodes, in residential areas embraced the informal self-organising processes (informal retail trade places, self-parking places, etc.) during the last 25 years of post-socialist time. The informal sector in retail trade in post-socialist city resulted "from a lack of trading space, the need of convenience and flexibility in retail locations, an absence of seed capital and week state regulations" [26]. The main urban spaces in the postsoviet cities, which had been influenced by informal retail trade, were open-air markets, sports stadia, sites around bus and rail stations, or metro stations. Partially, these informal trade sites appeared in the residential areas near sites around bus and metro stations, "informal trade on the streets and rail stations" [26], or chaotically expanding open-air markets in the form of self-organising processes and the features of stigmergic behaviour of retail trade participants. The informal sites of concentration of retail trade as self-organizing process were mostly situated in and around nodes in residential areas of large-scale post-socialist housing estates in the cities after 1991. This kind of trade function in the informal trade sites received the 
transformation of its form during the last 25 years from the "trade on 'a portable table', later to "kiosk as relatively stable feature of the post-Soviet urban space", and finally functional transformations of apartments on the ground floor of residential blocks from residence to commerce or services from 2000. This last form of functional transformations of apartments on the ground floors of prefabricated housing blocks from residential to commercial facility will be discussed in the case study analysis at section 3 of this paper, addressing to the concept of stigmergic behaviour. Together with the concentrated informal retail trade sites around metro stations, the process of non-systematic transformation of apartments on the ground level from residential function to commercial results as self-organising process of stigmergic behaviour of the actors (residents, retail trade participants, authorities) in the urban environment of the nodes.

However, today the state and the cities' authorities do not possess the clear strategies for: the urban regeneration of post-socialist residential areas; the redevelopment of nodes in residential areas; the ongoing functional transformations of ground floor residencies to commerce here, in particular.

\section{Research objectives and methodology}

\subsection{Research objectives:}

The central goal of the paper is to examine contemporary residential areas of low liveability with nodal places of logistics and services infrastructural networks, with an eye on existing urban policies and application of transdisciplinary concept of stigmergy in contemporary urban environment. This goal sets the next research objectives: (a) conceptualisation of stigmergic process in urban planning; (b) overview of socialist and postsocialist urban policies for residential areas; (c) stigmergic behaviour in the development of nodal places in residential areas.

Conceptualisation of stigmergic process in urban planning. Stigmergy anticipates the process of "indirect communication between actors in the shared environment" [27]. In case of urban planning and city development, it becomes important to understand that the process of development occupies certain time, is produced by different institutions as continuous process. On this basis, we suggest to look on the stigmergic process in urban planning during time and define the types of shared environments as contexts in the urban system networks. Urban planning as a complex process embraces the design procedures fulfilled by design institutions, which continue the ongoing development of the settlements. We may trace the indirect communication during the urban planning process between different actors or participants (human: architects, citizens; non-tangible: ideology, needs, other) in the shared environments with various contexts (duration of time; urban area as place; functional actions, etc.). Hence, this kind of indirect continuous process of development in the content of urban planning in its different levels (institutional level; design level; economics conditions) of actions is carried out in the frames of features and meaning of stigmergy transferred to human practises as transdisciplinary approach. The process as actions done by actors of the environment and are using indirect communications to continue the previously finished action conclude the stigmergic behaviour. Thus, we suggest to define the categories of environments and contexts for conceptualization of stigmergic process in urban planning as follows: (a) contexts/ environments: Actors, Time, Place, Actions; (b) levels: Economics, Institutional, and Design. 
Overview of socialist and post-socialist urban policies for residential areas. The research is contextualized within the environment of post-socialist residential areas in Ukraine. The aim of this objective for the research is to look on the category of Time and conditions of design in the framework of the concept of stigmergy. The category of Time crucially divides the conditions of design process in the post-socialist country to socialist and postsocialist eras as following: (a) the socialist ideology is always inside the design process as administrative centralized design process fulfilled by state institutions during socialist era; (b) design process is carrying out by restructured state design institutions and new private design entities during post-socialist time. Here the Institutional and Design levels are connected between each other by certain time. The organizational changes of forms of owner of design institutions result on the scale of design processes, implementation or lack of urban planning strategies in the urban networks and nodes. Especially, we may trace the changes in urban environment of post-socialist cities, which possess chaotic interventions in urban tissue, especially in the post-socialist residential areas. The non-systematic changes in urban environment as residential areas and nodal places were and are appearing mostly as selforganized process have been done by actors (citizens, private owners, entrepreneurs). These non-systematic changes have been taking place with the nature of stigmergic behaviour: the process as actions (change $\mathrm{n}$ ) done by actors (citizens, etc.) of the shared environment (residential area) and are using indirect communications (demand, needs, result of the done action) to continue the previously finished action (change n-1). Hence, a self-organizing process with non-systematic changes appears, because of lack of urban policies. This reason underlines the meaning of urban policies as conditions for efficient stigmergic behaviours.

The urban policies for residential areas during socialist and post-socialist time in Ukraine embraced accordingly opposite ideological approaches. However, the contemporary urban policies for residential function are the reworked version of old rules and do not comprise the direct needs of living conditions. The development of urban policies, norms and rules we may follow in the next stages: (a) socialist era - in 1930, 1954, 1958, 1962, 1971, 1985, 1989; (b) post-socialist time - in 2003, 2005, 2011, 2015. These stages declared a very slow increase of quantity of living area per person in the residential buildings, principal structures of the housing and their typology, normative social services in the residential areas and their density.

Stigmergic behaviour in the development of nodal places in residential areas. Stigmergic behaviours take place under indirect communication in the environment. The process is influenced and triggered by environments and contexts: Actors, Time, Place, Actions; Economics, Institutional, Design (Tab. 1).

Table 1. Contexts of stigmergic behaviours.

\begin{tabular}{|c|c|c|c|c|c|}
\hline $\begin{array}{c}\text { Contexts/ } \\
\text { Environments }\end{array}$ & Actors & Time & Place & Actions & Reactions \\
\hline \multirow[b]{2}{*}{ Economics } & $\begin{array}{l}\text { State plan- } \\
\text { ning }\end{array}$ & 1917-1991 & City & $\begin{array}{c}\text { State trade, } \\
\text { State } \\
\text { property }\end{array}$ & \\
\hline & $\begin{array}{l}\text { Needs and } \\
\text { demands }\end{array}$ & $1991<2017$ & $\begin{array}{l}\text { Residential } \\
\text { areas }\end{array}$ & $\begin{array}{c}\text { Ground } \\
\text { Floor } \\
\text { Changes: } \\
\text { Commerce } \\
\text { and Services }\end{array}$ & $\begin{array}{c}\text { Create } \\
\text { nodal } \\
\text { places with } \\
\text { commerce, } \\
\text { market }\end{array}$ \\
\hline
\end{tabular}




\begin{tabular}{|c|c|c|c|c|c|}
\hline $\begin{array}{c}\text { Contexts/ } \\
\text { Environments }\end{array}$ & Actors & Time & Place & Actions & Reactions \\
\hline \multirow{2}{*}{ Institutional } & $\begin{array}{c}\text { Ideology } \\
\text { and politics }\end{array}$ & $1950-1991$ & $\begin{array}{c}\text { Urban } \\
\text { territories }\end{array}$ & $\begin{array}{c}\text { State Design } \\
\text { Institutes/ } \\
\text { Directive } \\
\text { planning }\end{array}$ & $\begin{array}{c}\text { Centralisa- } \\
\text { tion }\end{array}$ \\
\cline { 2 - 6 } & Democracy & $1991<2017$ & $-/ /-$ & $\begin{array}{c}\text { Private } \\
\text { Design } \\
\text { Institutions/ } \\
\text { Market }\end{array}$ & \\
\hline \multirow{2}{*}{ Design } & $\begin{array}{c}\text { State } \\
\text { Institutes }\end{array}$ & $1950-1991$ & $-/ /-$ & $\begin{array}{c}\text { Administra- } \\
\text { tive centra- } \\
\text { lized urban } \\
\text { planning }\end{array}$ & \\
\cline { 2 - 6 } & Architects & $1991<2017$ & $-/ /-$ & $\begin{array}{c}\text { Individual } \\
\text { projects }\end{array}$ & \\
\hline
\end{tabular}

\subsection{Methodology}

We used a case study approach to investigate the concept of stigmergy and stigmergic behaviour in urban planning. Consistent with the research focus and, hence, the research hypothesis, which is defined in the Introduction, the case study approach aims to identify the environments and contexts in urban areas, which stimuli stigmergic behaviours. The transdisciplinary theoretical framework opens application of the stigmergic concept in urban environment, and we draw attention to the developing urban societies, in particular to their residential areas and nodes. Stigmergic behaviour is defined as process of actions fulfilled by actors within the environment (contexts) under indirect communications (result of the action), which continue the previously finished action. Heylighen is defining "stigmergy as a mechanism of indirect coordination in which the trace left by an action in a medium stimulates subsequent actions" [18]. Thus, the process may continue unless there are changes in the context (time, economy).

Case study approach envisages the justification of the residential area, which includes actions done by actors in the environment during certain time. Research methods include the use of: (a) Earth Time Observation Systems (Google Earth Engine, Google Earth Pro) for identification of large-scale changes in the case study residential area during 1991-2017; (b) the micro-scale changes obtained by observation on the case study area. The large-scale changes in the case study residential area are the informal developments of retail trade and open-air markets around metro stations as nodes during 1991-2017. Google Earth Engine allows tracing these changes on the territory around the node during 1984-2016. The micro-scale changes in the case study residential area are the non-systematic functional transformations on the ground floors of residential blocks around nodes in post-socialist prefabricated housing estate built during the 1970-80s in Kharkiv, Ukraine. These functional transformations change residence apartments to commerce and services mostly not under urban policies. The data of micro-scale changes are obtained by on-site observations, since the data at Area (regional) Council authorities are not open as well as at the Department of statistics of Kharkiv.

The aim to identify the environments and contexts in urban areas, which stimuli 
stigmergic behaviours and work as trigger under the stigmergic concept. The physical environments and non-tangible contexts, where the actions are fulfilled by the actors in a continuous process, and take place during certain time form the frame of categories: place, time, economics, ideology, politics, infrastructures. The application of the transdisciplinary concept of stigmergy and stigmergic behaviours in urban planning envisage contextualization of changes (contexts and categories) and opens the field for improvement of urban policies, which could effectively continue or prevent the process.

\section{Case study: stigmergic behaviour and nodal places in residential area Saltivka District (Kharkiv)}

\subsection{Case study context}

Among the biggest cities of Ukraine is Kharkiv with the population of 1,45 m citizens (2016) [28]. This city received the prefabricated housing estates in 1950-80s. The scale of large post-socialist residential areas differed accordingly to the scale of the city. Thus, the biggest prefabricated residential area in Kharkiv is Saltivka with the population 385000 residents (2010) [29] and built during the 1970-80s.

Large-scale housing estate Saltivka is the biggest living area in Kharkiv, with largepanel multi-storeyed housing, developed during the 1970-80s, in the northeastern part of the city. The territory of living area Saltivka (Saltivka) occupies more than 700 hectares. The growth of population showed in 1977 - 250000 residents [30], $2010-385000$ residents [29]. The construction of Saltivka was performed according to the phases of micro districts' plan development until late 1980s, and enabled its rapid growth. Few new living blocks were built during last 15 years on the empty territories of Saltivka. Being the largest socialist housing estate in Ukraine, it comprises 22 micro districts. Each micro district was developed for 17500 residents on average. The typology of prefabricated buildings in Saltivka is based on the typical projects: large-panel 5-, 9-, 12-, 16-storeyed living blocks with linear, semilinear and tower structure. The planning system of housing in the territory designed in the free (open) planning. The ideology of micro district planning includes social services, green areas few sport facilities.

The micro-scale changes in the residential area are the functional transformations of the apartments on the ground floors of residential buildings built during the 1970-80s from 2000. This process began rather as self-organizing actions, than the mechanism under the urban policies.

The large-scale changes in the case study area are two sites: (a) the area around the node, which include metro station Heroyiv Pratsi, development of shopping malls in its northern direction and market that, had been started from informal retail trade as open-air market place; (b) the area around the node near the south part of residential area Saltivka, which include metro station Barabashovo and a large market area Barabashovo that had expanded to the territory of 75 hectares during 1995-2017 (Fig. 2). The part of the territory, where the retail market Barabashovo is situated now, was reserved for the train parking area of metro infrastructure in the masterplan of Kharkiv.

\subsection{Case study analysis: stigmergic behaviour and nodal places in residential area}


The data for the case study analysis of large-scale changes were obtained using Earth Time Observation Systems (Google Earth Engine, Google Earth Pro). Google Earth Engine gives the opportunity to trace the changes in the planning of the nodes in two sites of the case study during the timelapse for 1984-2016.

The area around the node with metro station Heroyiv Pratsi started to grow with informal retail trade as open-air market place from the time of the USSR collapsed in 1991. The change of politics ideology in 1991 was the moment, when the context received the changes on the market from state ownership to private ownership in economics and business. The time period during 1991-2017 is the context of time for stigmergic behaviour in the place. Here under the stigmergic behaviour we understand the function of retail trade, fulfilled by the actors (inhabitants, informal traders, and small entrepreneurs). The persuaded retail trade had been taking place as an open-air market on the closest to the metro station free open area. The function was spreading almost chaotically without any planning development during this time, only in 2006 two shopping malls and two stores were built in the northern west direction from the metro station. At the same time, the open-air market with the retail trade received small transformations of retail places, but these changes did not rise the quality of the function and services in the node. The actions (retail trade) done by actors under indirect communication, which continue the previously finished action in the place and within the contexts (time, economics). Hence, the above process is the stigmergic behaviour in the case study residential area with large-scale changes, which are showed by the selected satellite images with the residential area around the node with metro station Heroyiv Pratsi (Saltivka, Kharkiv) in 2000, 2008, 2012, 2016 retrieved from Google Earth Pro in 2017 (Fig. 1).
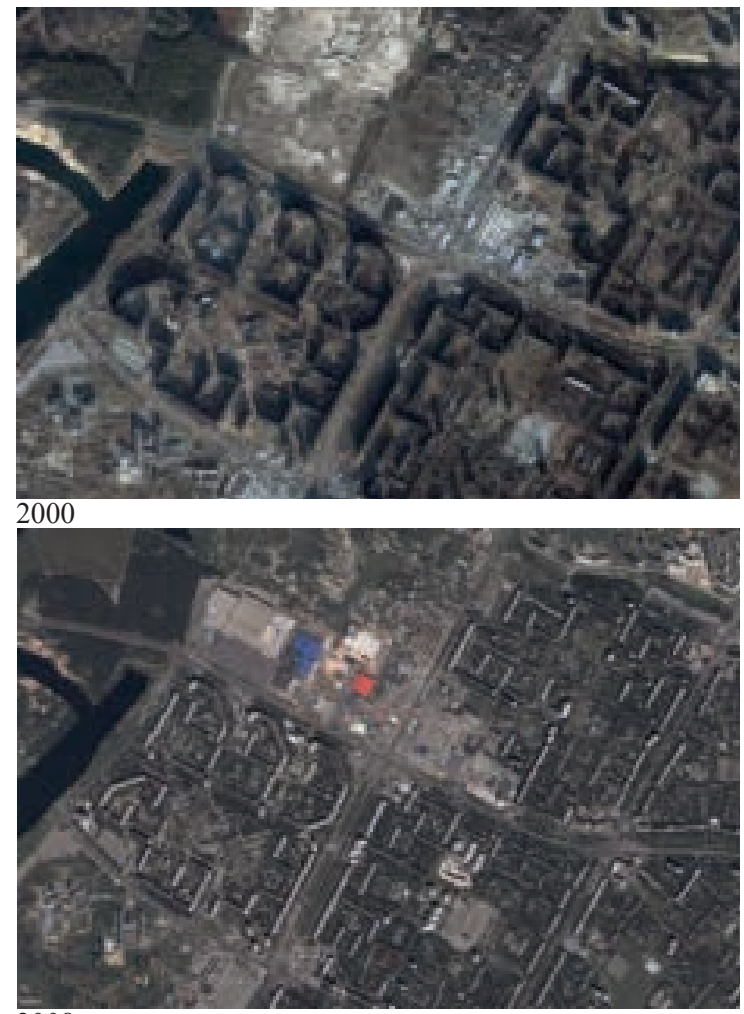

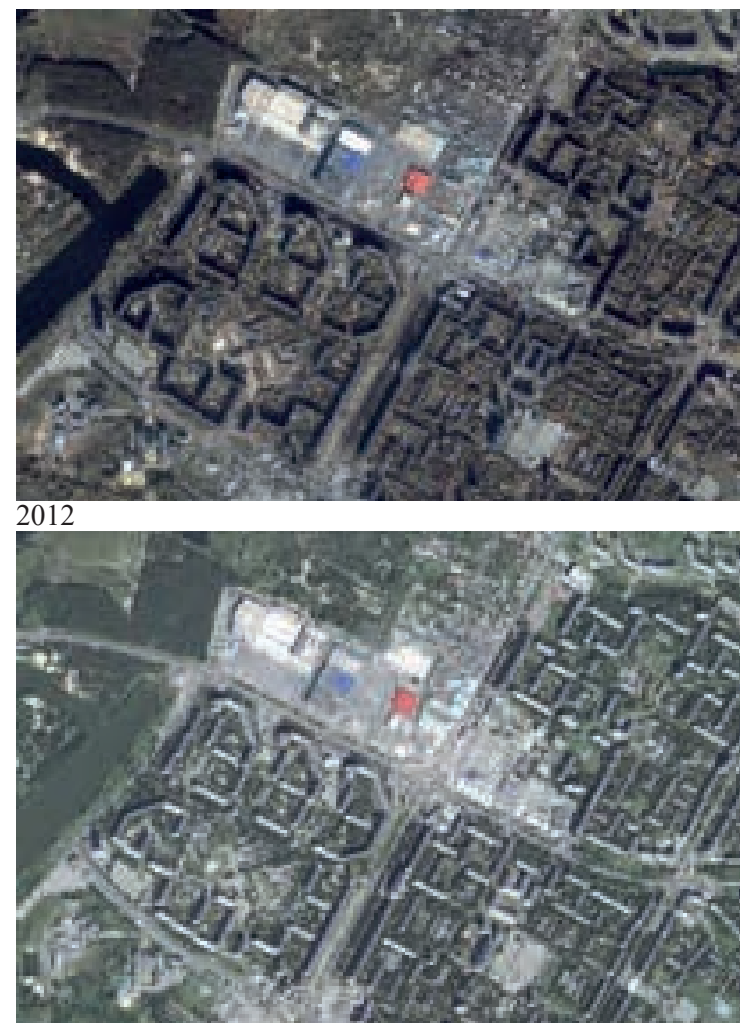

2016

Fig. 1. The residential area around the node with metro station Heroyiv Pratsi, Saltivka, Kharkiv. 2000, 2008, 2012, 2016 [Google Earth Pro; retrieved in 2017].

The large-scale changes in the case study area around the node near the south part of residential area Saltivka include metro station Barabashovo and a large market area Barabashovo. The retail trade function started to develop in 1995 here as open-air market with containers for retail trade and trade rows. During the last 22 years it spreaded to the territory of 75 hectares and became one of the biggest retail markets in the Eastern Europe. The growth did not have any adopted or proved development plan and was directed by the group of directors of the market, which received the positive solutions from the authorities. The traders in the market area Barabashovo were informal dealers and small entrepreneurs. The chaotic structure of the market does not fulfil the norms and standards for planning and development of market areas, as: norms of emergency and evacuation, insolation, ventilations, sanitation, sewerage. For instance, these lead to the fact that one of the entrances to the metro station by Academic Barabashov is tightly surrounded by the trade rows and makes it difficult for the ordinary inhabitant to find easily the right direction where the entrance to the metro is situated.

Here we see the process of stigmergic behaviour in the nodal place that is similar to the above area of the case study, where the actions (informal function) are taking place in the environment (place) and contexts (economics, politics) during time. These large-scale changes of the market area Barabashovo around the node with metro station by Academic Barabashov (Saltivka, Kharkiv) are observed on the data of satellite images (2000-2016) 
retrieved from Google Earth Pro in 2017. The selected satellite images from 2000, 2008, 2011, 2016 are showed (Fig. 2).

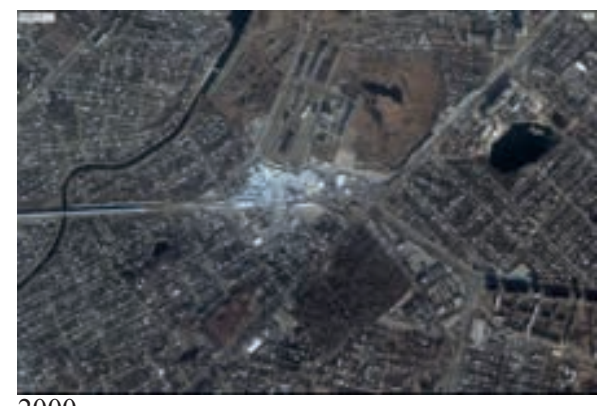

2000

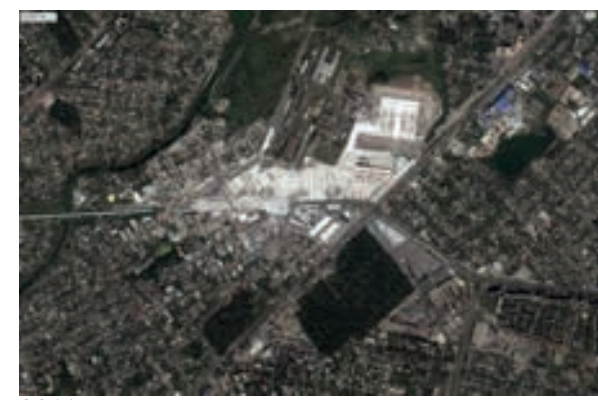

2011

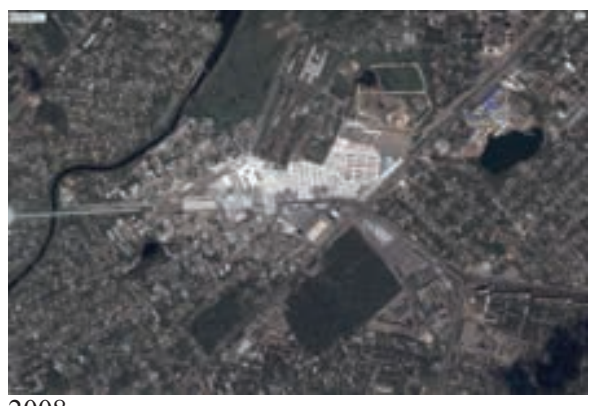

2008

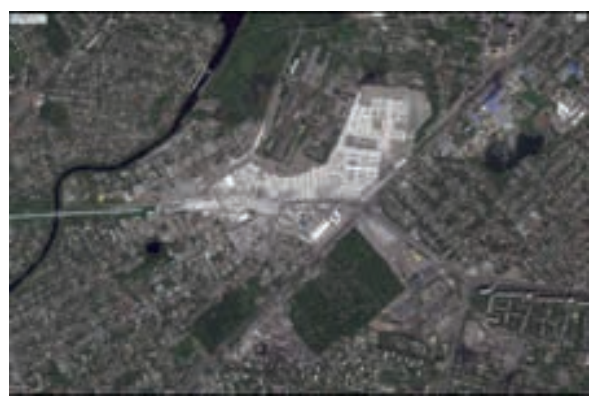

2016

Fig. 2. The market area Barabashovo around the node with metro station by Academic Barabashov, Saltivka, Kharkiv. 2000, 2008, 2011, 2016 [Google Earth Pro; retrieved in 2017] .

Functional transformations on ground floor of housing block in residential areas. The micro-scale changes in the case study residential area Saltivka are observed around the node with metro station Heroyiv Pratsi. The functional transformations of the apartments on the ground floors of residential buildings built during the 1970-80s started to take place from 2000. The process is not based under the strategic approach or any reconstruction program of the apartments. The mechanism of such functional transformation has the only formal step as official procedure of excluding of living square meters from housing function. This procedure is based on the apartment owner's application to the Area (regional) Council authorities and the final decision of these authorities. The urban policies define only the types of new excluded functions of services, which cannot be organised at the place, for instance (chemical storage, storage of recycled materials, etc.), and are not under any program or strategy of reconstruction. Thus, the owner of the property decides himself about a new function of commerce or services. The functional transformation causes as well the next reconstruction of the apartment as: construction of the individual entrance with the staircase to the facility from the street; reconstruction of the plan; construction of advertisement elements on the facade that belongs only to the facility; development of the entrance zone for the pedestrians and cars in the front of the facility; construction of the additional space of the facility in the front or at the backyard of the housing block (Fig. 3). 

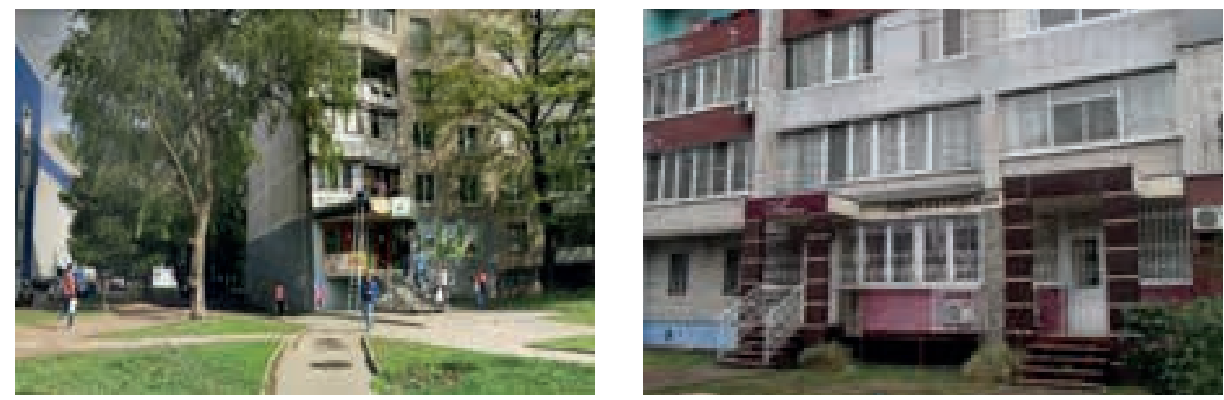

Fig. 3. Functional transformations on ground floor of housing block from residence to commerce and services in residential area Saltivka, Kharkiv [(c) Photos by O.Chabanyuk, 2017].

From residence to commerce and services as a stigmergic behaviour. The definition of stigmergic behaviour allows to understand functional transformations as actions fulfilled by residents or owners as actors in the process of functional transformations from residence to commerce within the environment (contexts) under indirect communications, which continue the previously finished action. Each action of transformation is a finished act, because the premises with the new function work successfully in the urban environment as a physical environment. The next place for the transformation is chosen by an owner of the residence himself, as well as the type of the function for the transformation. The only official step, which will allow this action is the application of the owner to the Area (regional) Council authorities and the obtaining of the official permission for the transformation, agreed design project. The commercial success of the services in the chosen location by the actor stimulates subsequent actions and plays the role of a trigger for another actor.

This example of the micro-scale changes in the urban environment in the case study allows to identify the cross-related stigmergic environments, which trigger the stigmergic behaviour. The stigmergic environments comprise physical (environment) and non-tangible spaces (context). This particular case study implicate the cross-related stigmergic environments: place, actions; and contexts as: time, economics, politics, ideology. Place as urban environment and urban tissue of the residential area is created under the politics and ideology (socialist state) of the 1970-80s. Contemporary time of 2017 starting from 1991 has changed the contexts of politics and ideology, but at the same time the urban environment of the residential area remains the same, hence the new rules of economics produce the context for stigmergic behaviour in the functional transformations in the residential areas in microand large-scale changes in the retail trade market.

\section{Discussion and conclusions}

Michael Batty (2013) expresses the vision about the contemporary urban environments that "it is high time we change our focus from locations to interactions, from thinking of cities as idealized morphologies to thinking of them as patterns of communications, interaction, trade and [...] thinking of them as networks" [7]. We envisage that the understanding of implication of interdisciplinary conceptual approach, as stigmergic concept will allow working with interaction of actors in urban environment under the self-organizing process. The contextualization of interaction in self-organizing process as stigmergic behaviour in urban area specifies the environments and contexts. Stigmergic approach provides the lens for us to understand how the environments and contexts influence and trigger the actors' 
actions. Stigmergic behaviour becomes a theoretical base for understanding the selforganizing process in urban space; describe emergent interactions of actors, reveals aim for equilibrium in urban planning. Stigmergy as a concept under the transdisciplinary application in urban planning provides capability to respond to shifting realities in the city development, its networks coordination.

Policy-making defines the frames for urban development, but not timely responds on the societal changes in the cities, which imply their own ways as self-organization process. However, it becomes the aim of urban policies to contextualize changes, which are under stigmergic behaviour, continue or prevent them, hence, direct to equilibrium in urban tissue. Stigmergic behaviours, as concept, are efficient, but work as a self-organization form.

Understanding that stigmergy can create efficiency without effectiveness, it's possible to assume and conclude that Urban Policies must seek and change the lack of effectiveness on stigmergic behaviours.

Urban policies must offer effectiveness to the stigmergic efficiency. Understanding emergent urban phenomenon as stigmergic behaviours can be translated to computational simulations in order to synchronize urban public demands to urban policies. Thus, urban policies must create effective policies.

With this preliminary understanding of transdisciplinary implication of stigmergic concept to urban planning, we envisage the general approach is still open in this domain for contributing to stigmergic capacity.

\section{Literature}

[1] Birk, R.H., Infrastructuring the social: Local community work, urban policy and marginalized residential areas in Denmark. . Environment \& Planning A., 2017. Vol. 49 (Issue 4): p. p767-783. $17 \mathrm{p}$.

[2] Judyta, W., Urban Infrastructure Facilities as an Essential Public Investment for Sustainable Cities - Indispensable but Unwelcome Objects of Social Conflicts. Case Study of Warsaw, Poland. Transportation Research Procedia, 2016. 16: p. 553-565.

[3] Cheng, J., et al., Understanding urban networks: Comparing a node-, a density- and an accessibilitybased view. Cities, 2013. 31: p. 165-176.

[4] Cheng, J., F.L. Clercq, and L. Bertolini, Understanding urban networks through accessibility. 2005, European Regional Science Association.

[5] Wdowiarz-Bilska, M., Concepts of the city in the AGE of knowledge-based economy. Czasopismo Techniczne; Architektura Zeszyt 12-A (27) 2015, 2016: p. 223-239.

[6] Newman, M.E.J., Networks : an introduction / M. E. J. Newman. 2010, Oxford: Oxford University Press.

[7] Batty, M., The New Science of Cities. 2013, Cambridge, Massachusetts: The MIT Press.

[8] Stouten, P.L.M., Changing Contexts in Urban Regeneration : 30 Years of Modernisation in Rotterdam. Design/Science/Planning. 2010, Amsterdam: Techne Press.

[9] New Urban Agenda. Draft outcome document of the United Nations Conference on Housing and Sustainable Urban Development (Habitat III), Quito, 17-20 October 2016. A/CONF.226/42016.

[10] Marsault, X., Can ants build urban street networks? 2009. p. 1706.

[11] Nickerson, J.V., Generating Networks. Design Computing and Cognition. Atlanta, 2008.

[12] Alfeo, A.L., et al., Stigmergy-based modeling to discover urban activity patterns from positioning data. 2017.

[13] Wohl, S., Considering how morphological traits of urban fabric create affordances for complex 
adaptation and emergence. Progress in Human Geography, 2016. 40(1): p. 30-47.

[14] Heylighen, F., Stigmergy as a Universal Coordination Mechanism: components, varieties and applications. Human Stigmergy: Theoretical Developments and New Applications. Springer. Retrieved from http://pespmc1. vub. ac. be/papers/stigmergy-varieties. pdf, 2015.

[15] Heylighen, F., Why is Open Access Development so Successful? Stigmergic organization and the economics of information. arXiv preprint cs/0612071, 2006.

[16] Christensen, L.R. Practices of stigmergy in architectural work. in Proceedings of the 2007 international ACM conference on Supporting group work. 2007. ACM.

[17] Mason, Z. Programming with stigmergy: using swarms for construction. in ICAL 2003: Proceedings of the eighth international conference on Artificial life. 2003.

[18] Heylighen, F., Stigmergy as a universal coordination mechanism I: Definition and components. Cognitive Systems Research, 2016. 38: p. 4-13.

[19] Gordon, D., Collective intelligence in social insects. AI-depot essay, available online at: http:// ai-depot. com/Essay/SocialInsects. html, 2004.

[20] Moura, L., Formigas, Vagabundos e Anarquia. LXXL Edições, 2003 (2009).

[21] Moura, L. Trails, Ants and Stigmergy 2017; Available from: http://www.leonelmoura.com/index. php/texts/trails-ants-and-stigmergy/.

[22] Zinchenko, M.Y., Zhylyshchnoe stroytelstvo v horodakh BSSR v seredyne 1950kh - 1960e hh. Pratsy histarychnaha fakulteta BDU, 2010( 5): p. 39-47.

[23] Yaremenko, L.V., Arkhitekturno-planuvalna orhanizatsiia prydomovykh prostoriv v novykh zhytlovykh raionakh naiznachnishykh mist /na prykladi Kyieva. Avtoref. of Dissertation, kand. arkh.: 18.00.04. 1993, Kyiv. nats. un-t bud-va i arkhit.

[24] Kharkiv Masterplan 2026. 2004; Available from: http://gromada.kh.ua/upload/userfiles/1/genplan. pdf.

[25] DBN 360-92** Mistobuduvannya. Planuvannya i zabudova mis'kykh i sil's'kykh poselen' (zi zminamy stanom na 21.06.2011). 2011.

[26] Bradshaw, M.J. and A. Stenning, East Central Europe and the Former Soviet Union : The PostSocialist States. DARG Regional Development Series. 2014, London: Routledge.

[27] Puusepp, R., Generating circulation diagrams for architecture and urban design using multi-agent systems. 2011, University of East London.

[28] State Statistics Service of Ukraine. [cited 2017; Available from: www.ukrstat.gov.ua

[29] Kharkiv City Council. [cited 2017; Available from: www.city.kharkov.ua.

[30] Ystoryia ulyts y ploshchadei Kharkova. Saltovskyi zhyloi massyv. Kharkiv

1977. 